\title{
Original
}

\section{A STUDY ON CARIES PREVENTION EFFECTS OF DENTIFRICES CONTAINING SODIUM MONOFLUOROPHOSPHATE, SODIUM MONOFLUOROPHOSPHATE PLUS DEXTRANASE, AND SODIUM MONOFLUOROPHOSPHATE PLUS SODIUM PHOSPHATE}

\author{
Teruo NIWA*, Kyūe BABA** and Motoo NIWA*
}

\begin{abstract}
Schoolchildren were asked to use dentifrices containing three different agents for one year: the agents were sodium monofluorophosphate, sodium monofluorophosphate plus dextranase, and sodium monofluorophosphate plus sodium phosphate. The caries prevention effects of these dentifrices were studied. The group of children who used dentifrice containing $0.76 \%$ sodium monofluorophosphate showed a $25.5 \%$ caries inhibition rate, and a statistically significant difference was observed in the rate of DF surfaces which increased during the test period in contrast to the control group. A significant difference was also found between the group of children who used dentifrice containing sodium monofluorophosphate alone and another group of children who used dentifrice containing sodium monofluorophosphate plus dextranase $(15,000$ units/g dentifrice added to sodium monofluorophosphate). An addition of dextranase resulted in an increase of $16.8 \%$ in the rate of caries inhibition. Another group of children who used dentifrice containing sodium monofluorophosphate to which $3 \%$ sodium phosphate was added showed a $4.6 \%$ higher caries inhibition rate than that shown in the group using dentifrice containing sodium monofluorophosphate alone, but there was no statistically significant difference in the rate of increased DF surfaces between these two groups. Furthermore, the caries prevention effects by tooth type and tooth surface were also evaluated for these three kinds of dentifrice. Moreover, it was confirmed that a continuous use of these four dentifrices over the period of one year did not result in oral anomalies either subjectively nor objectively.
\end{abstract}

\section{Introduction}

Today fluoride is the most effective agent in caries prevention, and has been applied

* Department of Hygiene, Nippon Dental College

** The Lion Foundation of Dental Health (Director: Shinichi SATO) Present address: Department of Oral Microbiology, Kanagawa Dental College

*日本歯科大学衛生学教室

*財団法人ライオン歯科衛生研究所（部長 佐藤新一） 現在 神奈川歯科大学口腔細菌学教室 昭和 50 年 8 月 15 日受付 
in different ways, such as in application to solutions, tablets, pastes, dentifrices, or in drinking water. The addition of fluoride to dentifrices is effective in view of safety and daily use, and the benefit has been demonstrated in many previous studies ${ }^{1-12}$. As the tolerance amount of fluoride adding to the dentifrice should, however, be below $1,000 \mathrm{ppm}$ in Japan ${ }^{13)}$, it is necessary to supplement the effect of fluoride or to add another agent with a different effect from that of fluoride in order to achieve a greater preventive effect. An application of dentifrice which does not produce insoluble calcium fluoride $\left(\mathrm{CaF}_{2}\right)$ in a reaction with fluorine ion has been conventionally done $e^{3,8,14}$, but sodium monofluorophosphate $\left(\mathrm{Na}_{2} \mathrm{PO}_{3} \mathrm{~F}\right.$, monoflo) takes the form of a complex salt $\left(\mathrm{PO}_{3} \mathrm{~F}^{2-}\right)$ and $\mathrm{CaPO}_{3} \mathrm{~F}$ producing by the reaction with calcium ion and $\mathrm{PO}_{3} \mathrm{~F}^{2-}$ has about $1 \%$ solubility ${ }^{15)}$. Therefore monoflo has the characteristic that it does not reduce the soluble fluoride amount in the use of dentifrice with calcium.

Dextranase has been known to dissolve plaque and prevent plaque accumulation by acting on the dextran in plaque ${ }^{16-20)}$, and is reported to have a caries prevention effect in experimental animals ${ }^{21-23)}$. It has been reported that sodium phosphate prevents caries generation in men through buffering effect of plaque to acid and calcification of teeth when added to foodstuffs ${ }^{24,25)}$.

In the present study dentifrices have been formulated by adding dextranase or sodium phosphate to monoflo, and the caries prevention effects have been evaluated in comparison with the case of monoflo alone.

\section{Subjects and Methods}

About 1,400 schoolchildren in the third, fourth, and fifth grade of elementary school were selected as subjects. Caries examination was done on the permanent teeth of all subjects with a dental mirror and an explorer. Then children were divided into groups so that caries incidence might be equal in the control group and each three test groups by grade as shown

Table 1. Rate of DF surfaces by dentifrice group and by grade at the initial examination

\begin{tabular}{|c|c|c|c|c|}
\hline $\begin{array}{c}\text { Dentifrice } \\
\text { Grade }\end{array}$ & $\mathrm{C}$ & M & $\mathrm{MD}$ & MP \\
\hline 3 & 5.79 & 5.67 & 5.97 & 5.82 \\
\hline 4 & 5.47 & 5.57 & 5.71 & 5.87 \\
\hline 5 & 5.34 & 5.21 & 5.16 & 5.14 \\
\hline Mean & 5.53 & 5.45 & 5.61 & 5.61 \\
\hline
\end{tabular}

C dentifrice group: Using a control dentifrice

$\mathrm{M}$ dentifrice group : Using a dentifrice containing $0.76 \% \mathrm{mo}$ noflo

MD dentifrice group: Using a dentifrice containing $0.76 \%$ monoflo and dextranase (About 15,000 units/g dentifrice)

MP dentifrice group: Using a dentifrice containing $0.76 \%$ monoflo and $3 \%$ sodium phosphate 
Table 2. Composition of dentifrices

\begin{tabular}{l|c|c|c|c}
\hline \multicolumn{1}{c|}{ Components } & C dentifrice & M dentifrice & MD dentifrice & MP dentifrice \\
\hline Dicalcium phosphate & $45.0 \%$ & $45.0 \%$ & $45.0 \%$ & $45.0 \%$ \\
Binding agent and & 22.0 & 22.0 & 22.0 & 22.0 \\
humectant & 1.8 & 1.8 & 1.8 & 1.8 \\
Foaming agent & - & 0.76 & 0.76 & 0.76 \\
Monoflo & - & - & 15,000 units $/ \mathrm{g}$ & - \\
Dextranase* & - & - & paste & 3.0 \\
Sodium phosphate & & & - &
\end{tabular}

Flavor, saccharin and purified water are added to the above to make the whole amount $100(\mathrm{wt}) \%$.

* Units of dextranase : $0.5 \mathrm{ml}$ of enzyme solution is added to $1 \mathrm{ml}$ of dextran solution [made through a process of solving dextran ( 5 million- 40 million in molecular weight) produced by Tokyo Kasei Kogyo Co., Ltd. into M/10 phosphate buffer ( $\mathrm{pH}$ 7.0)], which results in reducing power after ten-minute reaction at $35^{\circ} \mathrm{C}$. This reducing power is measured by 3,5-dinitrosalicylic acid method. Then dextranase which produces a reducing power corresponding to $1 \mu \mathrm{g}$ glucose per minute is determined to be 1 unit.

in Table 1. Subjects were examined by the same examiner both at the initial examination and that one year after the study in order to make dispersion in data minimum.

Composition of dentifrices that children used during the study is presented in Table 2. The $\mathrm{C}$ dentifrice as a control contains dicalcium phosphate for a dentifrice grade, a binding agent, and a foaming agent as main components. The $M$ dentifrice has $0.76 \%$ monoflo added to the $\mathrm{C}$ dentifrice. The MD dentifrice has $0.76 \%$ monflo and dextranase (about 15,000 units/g) added and the MP dentifrice has $0.76 \%$ monoflo and $3 \%$ sodium phosphate added to the $\mathrm{C}$ dentifrice.

The dextranase used in the present study is crude enzyme of what is produced by giving dextran to Chaetomium gracile ${ }^{19)}$. It has been proved to have no adverse effects in acute $^{26)}$ and chronic ${ }^{27)}$ toxicity exammination, skin and mucosa examination ${ }^{28,29)}$, and on leukocytes ${ }^{30)}$. And a recent report has shown a result that no anomalies were observed in a clinical examination of oral mucosa with the use of the dextranase ${ }^{31}$. As for sodium phosphate, $\mathrm{Na}_{2} \mathrm{HPO}_{4}$ and $\mathrm{NaH}_{2} \mathrm{PO}_{4}$ were used and both were adequately mixed to make $\mathrm{pH}$ 7.0 7.3.

The subjects received these dentifrices every month. At school they brushed their teeth after lunch every other day under the supervision of their homeroom teachers. At home brushing was done twice daily, morning and evening. During summer and winter vacation brushing at home was done three times a day, including after lunch, and the performance behavior was reported in the form of a diary.

Soluble fluoride concentration and active dextranase amount in monflo-containing dentifrices used by the children are shown in Table 3. A statistically significant difference was not observed in soluble fluoride concentration in the M, MD and MP dentifrices, which was an average of $901 \mathrm{ppm}, 884 \mathrm{ppm}$ and $912 \mathrm{ppm}$ respectively.

The mean active value of dextranase was 14,500 units/g dentifrice. 
Table 3. Amounts of soluble fluoride and active dextranase in dentifrice

\begin{tabular}{|c|c|c|c|c|c|c|c|c|}
\hline \multicolumn{2}{|c|}{ Components } & \multicolumn{2}{|c|}{ Dentifrice } & $\begin{array}{l}1971 \\
\text { May }\end{array}$ & June & July & August & September \\
\hline \multirow{3}{*}{\multicolumn{2}{|c|}{$\begin{array}{l}\text { Amounts of } \\
\text { soluble } \\
\text { fluoride }\end{array}$}} & & M & 908 & 877 & 840 & 840 & 965 \\
\hline & & & $\mathrm{MD}$ & 911 & 893 & 875 & 826 & 881 \\
\hline & & & MP & 945 & 923 & 826 & 893 & 915 \\
\hline \multicolumn{2}{|c|}{$\begin{array}{l}\text { Amount of } \\
\text { active } \\
\text { dextranase }\end{array}$} & \multicolumn{2}{|c|}{ MD } & 13,900 & 14,200 & 15,100 & 12,600 & 13,400 \\
\hline October & \multicolumn{2}{|c|}{ November } & December & $\begin{array}{c}1972 \\
\text { January }\end{array}$ & February & March & April & Mean \\
\hline 889 & \multicolumn{2}{|c|}{955} & 870 & 938 & 916 & 907 & 910 & 901 \\
\hline 844 & \multicolumn{2}{|c|}{933} & 859 & 912 & 899 & 892 & 886 & 884 \\
\hline 896 & \multicolumn{2}{|c|}{929} & 943 & 951 & 918 & 888 & 912 & 912 \\
\hline 11,500 & \multicolumn{2}{|c|}{15,900} & 16,300 & 16,000 & 16,200 & 15,100 & 14,100 & 14,500 \\
\hline
\end{tabular}

Amount of soluble fluoride : ppm Amount of active dextranase : unit/g dentifrice

The fluoride concentration of drinking water at schools was $0.08 \mathrm{ppm}$ on the average as shown in Table 4. Fluoride quantification was measured by the use of alizarin complexion method $^{32)}$.

As these four dentifrices were used continuously over the period of one year in the present study, intraoral subjective and objective conditions were observed at the beginning of the study, six months and one year after in order to confirm the presence of adverse effects of these four dentifrices used in the experiments.

\section{Results}

The number of all teeth surfaces, number of DF surfaces, rate of DF surfaces, and number of subjects, excluding children who changed schools during the study period and who were absent from examinations, and whose caries incidence status were extremely severe, are presented in Table 5 by type of dentifrice and grade. Data obtained after one year includes teeth which erupted during the study period.

Caries prevention effects of each dentifrice were evaluated in the following four cases :

1) Using data of the rate of DF surfaces of all teeth at the start and completion of the study.

2) Classifying data of all teeth into teeth which erupted during the study period (newly erupted teeth) and teeth which had already erupted at the beginning of the study (existing teeth).

3) Classifying the existing teeth to anterior teeth and molars.

4) Classifying molars to mesial-distal surfaces, buccal-lingual surfaces, and occlusal 
Table 4. Fluoride concentration in drinking water of elementary schools

\begin{tabular}{c|c}
\hline Elementary school & Fluoride concentration (ppm) \\
\hline A & 0.092 \\
B & 0.079 \\
C & 0.060 \\
D & 0.090 \\
\hline Mean & 0.080
\end{tabular}

Table 5. Rate of DF surfaces and number of subjects at the initial examination and that one year after the study

\begin{tabular}{|c|c|c|c|c|c|c|c|c|c|}
\hline \multirow{2}{*}{ Grade } & \multirow{2}{*}{ Item } & \multicolumn{2}{|c|}{ C dentifrice group } & \multicolumn{2}{|c|}{ M dentifrice group } & \multicolumn{2}{|c|}{ MD dentifrice group } & \multicolumn{2}{|c|}{ MP dentifrice group } \\
\hline & & Initial & $\begin{array}{l}\text { One year } \\
\text { later }\end{array}$ & Initial & $\begin{array}{l}\text { One year } \\
\text { later }\end{array}$ & Initial & $\begin{array}{l}\text { One year } \\
\text { later }\end{array}$ & Initial & $\begin{array}{c}\text { One year } \\
\text { later }\end{array}$ \\
\hline \multirow{4}{*}{3} & $\begin{array}{l}\text { Total } \\
\text { number } \\
\text { of } \\
\text { surfaces }\end{array}$ & 4,929 & 6,395 & 6,578 & 8,502 & 7,069 & 9,445 & 4,792 & 6,310 \\
\hline & $\begin{array}{l}\text { Number } \\
\text { of DF } \\
\text { surfaces }\end{array}$ & 286 & 486 & 380 & 602 & 405 & 625 & 276 & 442 \\
\hline & $\left|\begin{array}{l}\text { Rate of DF } \\
\text { surface }(\%)\end{array}\right|$ & 5.80 & 7.60 & 5.78 & 7.08 & 5.73 & 6.62 & 5.76 & 7.00 \\
\hline & \begin{tabular}{|l|} 
Number \\
of \\
subjects
\end{tabular} \mid & \multicolumn{2}{|r|}{87} & \multicolumn{2}{|r|}{120} & \multicolumn{2}{|c|}{128} & \multicolumn{2}{|r|}{88} \\
\hline \multirow{4}{*}{4} & $\begin{array}{l}\text { Total } \\
\text { number } \\
\text { of } \\
\text { surfaces }\end{array}$ & 6,752 & 8,381 & 7,897 & 9,926 & 8,668 & 10,893 & 8,396 & 10,426 \\
\hline & $\begin{array}{l}\text { Number } \\
\text { of DF } \\
\text { surfaces }\end{array}$ & 377 & 600 & 443 & 670 & 491 & 717 & 474 & 703 \\
\hline & $\begin{array}{l}\text { Rate of DF } \\
\text { surface }(\%)\end{array}$ & 5.58 & 7.16 & 5.61 & 6.75 & 5.66 & 6.58 & 5.65 & 6.74 \\
\hline & $\begin{array}{l}\text { Number } \\
\text { of } \\
\text { subjects }\end{array}$ & \multicolumn{2}{|r|}{93} & \multicolumn{2}{|r|}{114} & \multicolumn{2}{|r|}{120} & \multicolumn{2}{|r|}{120} \\
\hline \multirow{4}{*}{5} & $\begin{array}{l}\text { Total } \\
\text { number } \\
\text { of } \\
\text { surfaces }\end{array}$ & 8,116 & 9,575 & 8,698 & 10,499 & 8,431 & 10,110 & 11,080 & 13,372 \\
\hline & $\begin{array}{l}\text { Number } \\
\text { of DF } \\
\text { surfaces }\end{array}$ & 442 & 674 & 477 & 708 & 459 & 655 & 606 & 884 \\
\hline & $\begin{array}{l}\text { Rate of DF } \\
\text { surface }(\%)\end{array}$ & 5.45 & 7.04 & 5.48 & 6.74 & 5.44 & 6.48 & 5.47 & 6.61 \\
\hline & \begin{tabular}{|l|} 
Number \\
of \\
subjects
\end{tabular} \mid & \multicolumn{2}{|r|}{90} & \multicolumn{2}{|r|}{101} & \multicolumn{2}{|r|}{97} & \multicolumn{2}{|r|}{129} \\
\hline
\end{tabular}

surfaces.

Variance analysis with two-way lay out with two factors, group using dentifrice (dentifrice groups) and grade was used to analyse the data. In the case that groups were signifi- 
Table 6. Increased DF surface rate

\begin{tabular}{|c|c|c|c|c|}
\hline $\begin{array}{cc} & \text { Dentifrice } \\
\text { Grade } & \text { group** }\end{array}$ & $\mathrm{C}$ & M & $\mathrm{MD}$ & MP \\
\hline 3 & 1.80 & 1.30 & 0.89 & 1.24 \\
\hline 4 & 1.58 & 1.14 & 0.92 & 1.09 \\
\hline 5 & 1.59 & 1.26 & 1.04 & 1.14 \\
\hline Mean & 1.66 & 1.23 & 0.95 & 1.16 \\
\hline
\end{tabular}

** The risk is significant, $1 \%$ between dentifrice groups.

Table 7. Comparison of significance between dentifrice groups of all teeth

\begin{tabular}{c|c|c|c}
\hline Dentifrice group & $\mathrm{M}$ & $\mathrm{MD}$ & $\mathrm{MP}$ \\
\hline $\mathrm{C}$ & $* *$ & $* *$ & $* *$ \\
\hline & $\mathrm{M}$ & $\begin{array}{c}* * \\
\text { (effect of }+\mathrm{D})\end{array}$ & \begin{tabular}{c} 
(effect of $+\mathrm{P})$ \\
\cline { 2 - 3 }
\end{tabular} \\
\hline & $\mathrm{MD}$ & $\begin{array}{c}* \\
(\text { difference between the effect } \\
\text { of }+\mathrm{D} \text { and that of }+\mathrm{P})\end{array}$
\end{tabular}

**: Significant difference with $1 \%$ risk.

*: Significant difference with $5 \%$ risk.

$+D$ : The effect caused by an addition of dextranase, and so forth.

$+\mathrm{P}$ : The effect caused by an addition of sodium phosphate, and so forth.

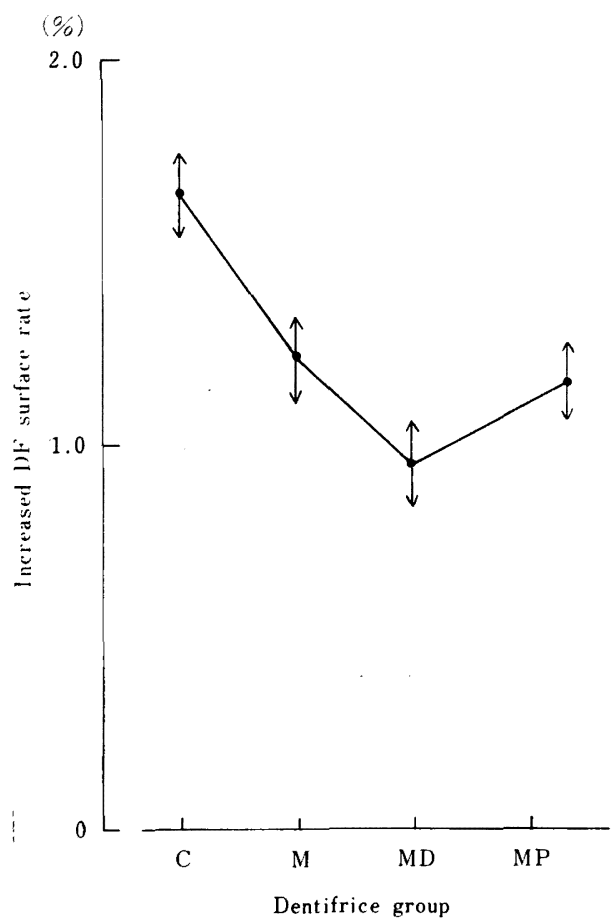

Width of an arrow shows $95 \%$ confidence interval of population mean.

Fig. 1 A graph of interval estimation of all teeth. 
cant, comparison of significance between dentifrice groups was conducted in evaluation ${ }^{33)}$.

1) Using data of all teeth at the start and completion of the study.

The increased DF surface rate, difference of the rate of DF surfaces of the completoin of the study and that at the beginning of the study, is shown in Table 6. Variance analysis with two-way lay out with two factors of dentifrice groups and grade using this increased DF surface rate resulted in significance of $1 \%$ risk between dentifrice groups but there was no significance between grade.

The mean increased DF surface rate and $95 \%$ confidence interval of population mean in each dentifrice group are shown in Fig. 1. The mean increased DF surface rate in the C, $\mathrm{M}, \mathrm{MD}$, and MP dentifrice groups is $1.66 \%, 1.23 \%, 0.95 \%, 1.15 \%$ respectively.

The significance comparison between dentifrice groups is shown in Table 7. There is a significant difference with $1 \%$ risk between increased DF surface rate in the $\mathrm{C}$ dentifrice group and that in each experimental dentifrice group containing monoflo. Therefore the caries prevention effect of monoflo is confirmed.

There is also a significant difference with $1 \%$ risk between the $\mathrm{M}$ dentifrice group and MD dentifrice group, the increased DF surface rate in the MD dentifrice group being smaller, which means the caries prevention effect is enhanced by the addition of dextranase.

Furthermore there is a significant difference with $5 \%$ risk between the MD dentifrice group and MP dentifrice group. The increased DF surface rate is smaller in the MP dentifrice group, which shows that the effect caused by an addition of dextranase is apparently larger than that caused by an addition of sodium phosphate. The increased DF surface rate is smaller in the MP dentifrice group than in the M dentifrice group, but the difference between these two groups is not significant.

Caries inhibition rate of three experimental groups as contrasted with the $\mathrm{C}$ dentifriec group, shown in Table 8 , is sought as follows :

Caries inhibition rate

$$
\begin{aligned}
& \text { Increased DF surface rate in the } C \text { dentifrice group-Increased DF surface } \\
& \text { rate in the experimental dentifrice group } \\
& \text { Increased DF surface rate in the } \mathrm{C} \text { dentifrice group }
\end{aligned}
$$

In the $\mathrm{M}$ dentifrice group, caries inhibition rate in the third and fourth grade is about the same $27.8 \%$ and $27.9 \%$ respectively, and $20.8 \%$ in the fifth grade, the inhibition effect by monoflo being reduced a little. In the MD dentifrice group, it is equal in the third and fourth

\begin{tabular}{|c|c|c|c|c|}
\hline $\begin{array}{cc} & \text { Dentifrice } \\
\text { Grade } & \text { group } \\
\end{array}$ & $\mathrm{C}$ & M & MD & MP \\
\hline 3 & - & 27.8 & 50.6 & 31.1 \\
\hline 4 & $\longrightarrow$ & 27.9 & 41.8 & 31.0 \\
\hline 5 & - & 20.8 & 34.6 & 28.3 \\
\hline Mean & - & 25.5 & 42.3 & 30.1 \\
\hline
\end{tabular}
grade, $31.1 \%$ and $31.0 \%$ respectively, and $28.3 \%$ in the fifth grade, the inhibition effect by

Table 8. Caries inhibition rate of all teeth 


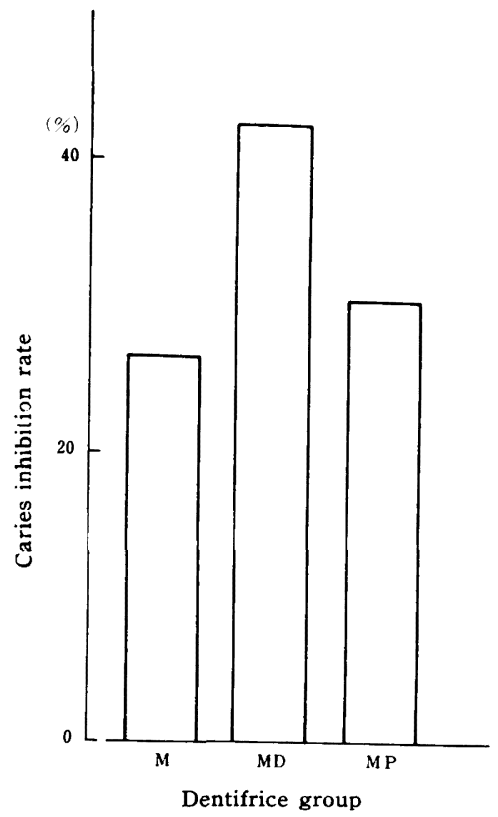

Fig. 2 Mean caries inhibition rate in grades of dentifrice.

monoflo being reduced a little, showing the same tendency as the $\mathrm{M}$ dentifrice group.

The mean caries inhibition rate in the grades is $25.5 \%$ in the $\mathrm{M}$ dentifrice group, $42.7 \%$ in the MD dentifrice group, and $30.1 \%$ in the MP dentifrice group as shown in Fig. 2. Increase in caries inhibition rate when dextranase 15,000 units is added per $1 \mathrm{~g}$ dentifrice is $16.8 \%$, and when $3 \%$ sodium phosphate is added, it is $4.6 \%$.

2) Classifying data of all teeth into newly erupted teeth and existing teeth.

The classification of newly erupted teeth (teeth which erupted during the study period) and existing teeth (teeth which had already erupted by the start of the study) is shown in Table $9,10$.

In the case of newly erupted teeth in Table 9 , the number of carious surfaces is extremely few, and fluctuation of data is large, so the caries prevention effect of dentifrices cannot be made clear. In the case of existing teeth presented in Table 10, the number of teeth surfaces which had been healthy at the beginning of the study, but were affected by caries during the one year of the study is divided by the number of healthy teeth and multiplied by 100 , which is the rate of DF surfaces. Variance analysis with two-way lay out with two factors dentifrice groups and grade using the rate of DF surfaces resulted in significance in dentifrice groups and grade with $1 \%$ risk for each.

The mean DF surface rate and $95 \%$ confidence interval of the population mean in each dentifrice group and in grade are shown in Fig. 3. The mean DF surface rate is the greatest in $\mathrm{C}$ dentifrice group, followed by the $\mathrm{M}, \mathrm{MP}$, and $\mathrm{MD}$ dentifrice groups. The value is $3.39 \%, 2.95 \%, 2.85 \%$, and $2.63 \%$ respectively. 
Table 9. Rate of DF surfaces in newly erupted teeth surfaces

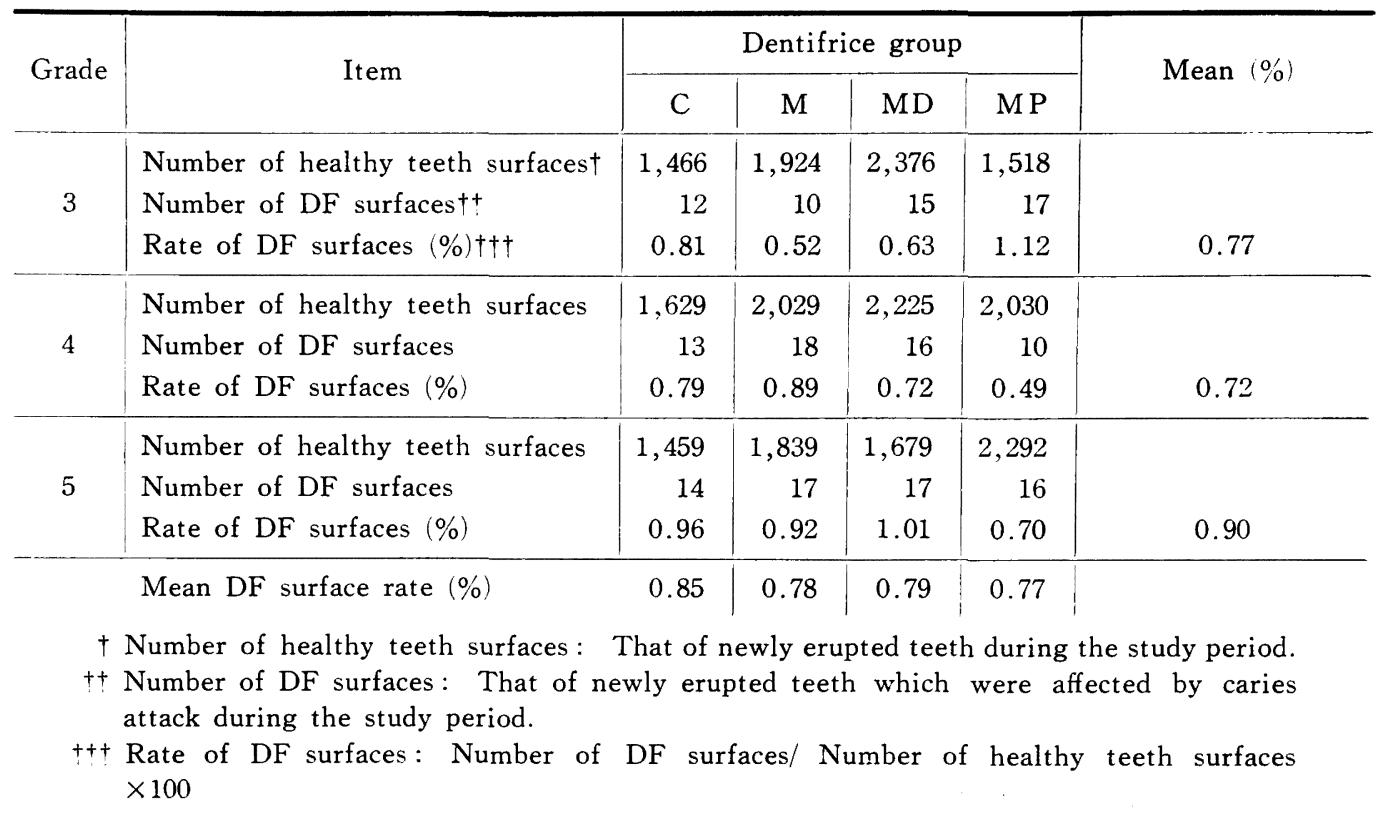

Table 10. Rate of DF surfaces and caries inhibition rate on existing teeth surfaces

\begin{tabular}{|c|c|c|c|c|c|c|}
\hline \multirow{2}{*}{ Grade } & \multirow{2}{*}{ Item } & \multicolumn{4}{|c|}{ Dentifrice group } & \multirow{2}{*}{ Mean $(\%)$} \\
\hline & & C & $\mathrm{M}$ & MD & $\mathrm{MP}$ & \\
\hline 3 & $\begin{array}{l}\text { Number of healthy teeth surfaces } \dagger \\
\text { Number of DF surfaces }{ }^{+} \\
\text {Rate of DF surfaces }(\%) \\
\text { Caries inhibition rate }(\%)\end{array}$ & $\begin{array}{r}4,643 \\
188 \\
4.05 \\
\end{array}$ & $\begin{array}{r}6,198 \\
212 \\
3.42 \\
15.6\end{array}$ & $\begin{array}{r}6,664 \\
205 \\
3.08 \\
24.0\end{array}$ & $\begin{array}{r}4,516 \\
149 \\
3.30 \\
18.5\end{array}$ & $\begin{array}{c}3.46 \\
19.4\end{array}$ \\
\hline 4 & $\begin{array}{l}\text { Number of healthy teeth surfaces } \\
\text { Number of DF surfaces } \\
\text { Rate of DF surfaces (\%) } \\
\text { Caries inhibition rate }(\%)\end{array}$ & $\begin{array}{r}6,375 \\
210 \\
3.29 \\
\end{array}$ & $\begin{array}{r}7,454 \\
209 \\
2.80 \\
14.9\end{array}$ & $\begin{array}{r}8,117 \\
210 \\
2.57 \\
21.9\end{array}$ & $\begin{array}{r}7,922 \\
219 \\
2.76 \\
16.1 \\
\end{array}$ & $\begin{array}{l}2.80 \\
17.6\end{array}$ \\
\hline 5 & $\begin{array}{l}\text { Number of healthy teeth surfaces } \\
\text { Number of DF surfaces } \\
\text { Rate of DF surfaces (\%) } \\
\text { Caries inhibition rate }(\%)\end{array}$ & $\begin{array}{r}7,674 \\
218 \\
2.84 \\
\end{array}$ & $\begin{array}{r}8,221 \\
214 \\
2.64 \\
7.0 \\
\end{array}$ & $\begin{array}{r}7,972 \\
179 \\
2.24 \\
21.1 \\
\end{array}$ & $\begin{array}{r}10,474 \\
262 \\
2.50 \\
12.0\end{array}$ & $\begin{array}{c}2.56 \\
13.4\end{array}$ \\
\hline & Mean DF surface rate $(\%)$ & 3.39 & 2.95 & 2.63 & 2.85 & \\
\hline & Mean caries inhibition rate $(\%)$ & $\longrightarrow$ & 12.5 & 22.3 & 15.5 & \\
\hline
\end{tabular}

+ Number of healthy teeth surfaces: That of teeth which had already erupted at the beginning of the study.

$\dagger \dagger$ Number of DE surfaces: That of existing teeth which had been affected by caries at the beginning of the study. 
The rate of $\mathrm{DF}$ surfaces reduces with increase of age, from $3.46 \%$ in the third grade, to $2.80 \%$ in the fourth grade and to $2.56 \%$ in the fifth grade.

The significance between dentifrice groups is shown in Table 11. There is a significant difference with $1 \%$ risk between the $\mathrm{C}$ dentifrice group and the $\mathrm{M}, \mathrm{MD}$, and MP groups.

The difference between the $M$ and $M D$ dentifrice groups is also significant with $1 \%$ risk, and that between the MD and MP dentifrice the group is significant with $5 \%$ risk. In existing teeth, the differences between the caries inhibition effect of monoflo and the enhancing effect of an addition of dextranase, and the effect of an addition of sodium phosphate are made clear.

The caries inhibition rate in the M, MD, MP dentifrice groups reduces with increase of age as shown in Table 10. The caries inhibition rate is sought by dividing the difference between the rate of DF surfaces in the $\mathrm{C}$ dentifrice group and that in experimental group by the rate of DF surfaces in the $\mathrm{C}$ dentifrice group, and by multiplying the difference by 100 .

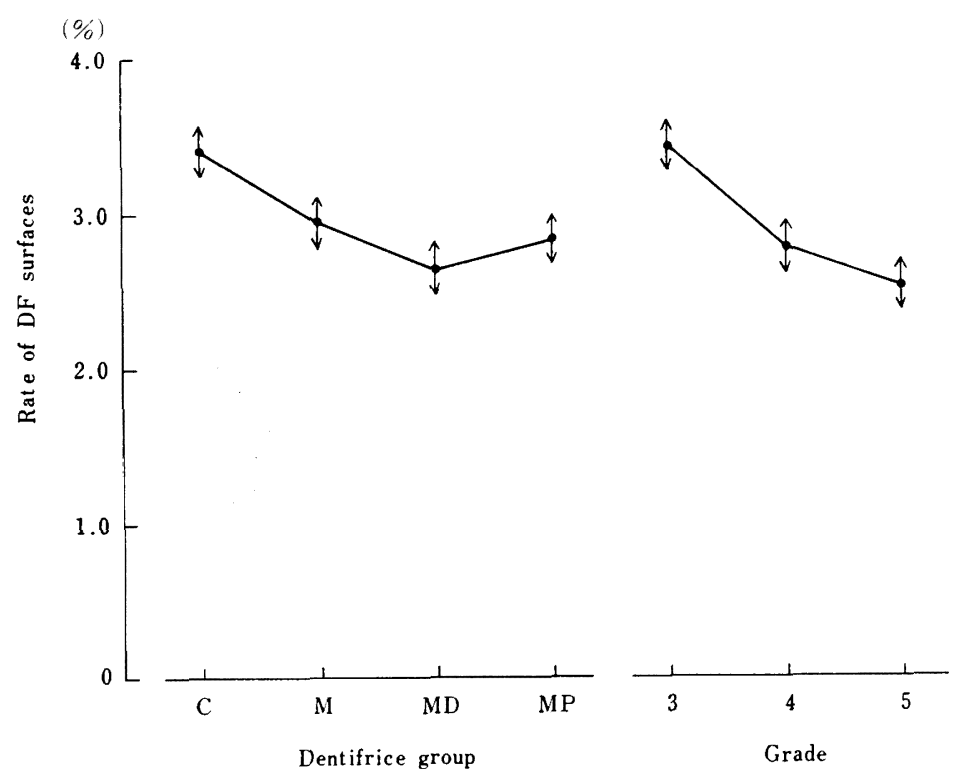

Fig. 3 A graph of interval estimation of existing teeth surfaces.

Table 11. Comparison of significance between dentifrice groups on existing teeth surfaces

\begin{tabular}{|c|c|c|c|}
\hline Dentifrice group & $\mathbf{M}$ & $\mathrm{MD}$ & MP \\
\hline \multirow[t]{3}{*}{$\mathrm{C}$} & $* *$ & $* *$ & $* *$ \\
\hline & $\mathbf{M}$ & $($ effect of $+D)$ & $($ effect of $+\mathrm{P})$ \\
\hline & & $\mathrm{MD}$ & $\begin{array}{l}\text { (difference between the effect } \\
\text { of }+D \text { and that of }+P \text { ) }\end{array}$ \\
\hline
\end{tabular}

** : Significant difference with $1 \%$ risk.

* : Significant difference with $5 \%$ risk. 
The mean caries inhibition rate in the grades is $12.5 \%$ in the $\mathrm{M}$ dentifrice group, $22.3 \%$ in the MD dentifrice group, and $15.5 \%$ in the MP dentifrice group. An addition of dextranase increases the rate by $9.7 \%$, and that of sodium phosphate by $3 \%$. The mean caries inhibition rate in the third grade is $19.4 \%$, that in the fourth grade is $17.6 \%$, and that in the fifth grade is $13.4 \%$.

3) Classifying the existing teeth into anterior teeth and molars.

The data of existing teeth in Table 10 is divided into those of anterior teeth and molars, shown in Table 12 and 13.

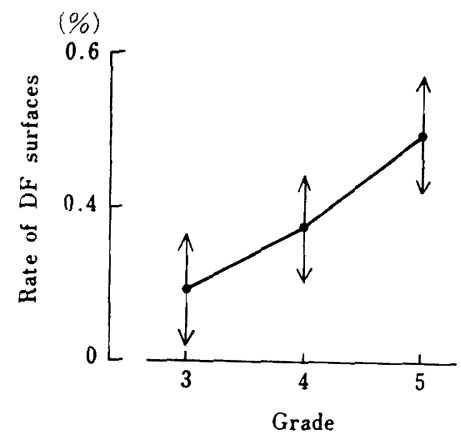

Fig. 4 A graph of interval estimation of anterior teeth surfaces

In the data of anterior teeth in Table 12, the number of carious surfaces is extremely few, similar to the case of newly erupted teeth. The caries inhibition effect of the dentifrices could not be demonstrated. Significance with $5 \%$ risk is found in grades. The mean DF surface rate is $0.19 \%$ in the third grade, $0.35 \%$ in the fourth grade, and $0.59 \%$ in the fifth grade, showing an increasing tendency with age, as illustrated in Fig 4.

Variance analysis of molar surfaces shown in Table 13 resulted in significance with $1 \%$ risk in both dentifrice groups and grades.

The rate of DF surfaces in each dentifrice group and grade is shown in Table 13 and

Table 12. Rate of DF surfaces on anterior teeth surfaces

\begin{tabular}{|c|c|c|c|c|c|c|}
\hline \multirow{2}{*}{ Grade } & \multirow{2}{*}{ Item } & \multicolumn{4}{|c|}{ Dentifrice group } & \multirow{2}{*}{ Mean (\%) } \\
\hline & & $\mathrm{C}$ & M & MD & MP & \\
\hline \multirow{3}{*}{3} & Number of healthy teeth surfaces & 2,622 & 3,639 & 3,882 & 2,565 & \\
\hline & Number of DF surfaces & 7 & 10 & & 3 & \\
\hline & Rate of DF surfaces (\%) & 0.27 & 0.27 & 0.10 & 0.11 & 0.19 \\
\hline \multirow{3}{*}{4} & Number of healthy teeth surfaces & 3,431 & 4,065 & 4,363 & 4,250 & \\
\hline & Number of DF surfaces & 11 & & 14 & 25 & \\
\hline & Rate of DF surfaces (\%) & 0.32 & 0.17 & 0.32 & 0.59 & 0.35 \\
\hline \multirow{3}{*}{5} & Number of healthy teeth surfaces & 3,872 & 4,152 & 4,030 & 5,268 & \\
\hline & Number of DF surfaces & 26 & 18 & 27 & 31 & \\
\hline & Rate of DF surfaces (\%) & 0.67 & 0.43 & 0.67 & 0.59 & 0.59 \\
\hline & Mean DF surface rate $(\%)$ & 0.42 & 0.29 & 0.36 & 0.43 & \\
\hline
\end{tabular}


Table 13. Rate of DF surfaces and caries inhibition rate on molar surfaces

\begin{tabular}{|c|c|c|c|c|c|c|}
\hline \multirow{2}{*}{ Grade } & \multirow{2}{*}{ Item } & \multicolumn{4}{|c|}{ Dentifrice group } & \multirow{2}{*}{ Mean (\%) } \\
\hline & & $\mathrm{C}$ & $\mathbf{M}$ & MD & MP & \\
\hline 3 & $\begin{array}{l}\text { Number of healthy teeth surfaces } \\
\text { Number of DF surfaces } \\
\text { Rate of DF surfaces (\%) } \\
\text { Caries inhibition rate (\%) }\end{array}$ & $\begin{array}{r}2,021 \\
181 \\
8.96 \\
\end{array}$ & $\begin{array}{r}2,559 \\
202 \\
7.89 \\
11.9\end{array}$ & $\begin{array}{r}2,782 \\
201 \\
7.23 \\
19.3\end{array}$ & $\begin{array}{r}1,951 \\
146 \\
7.48 \\
16.5\end{array}$ & $\begin{array}{c}7.89 \\
15.9\end{array}$ \\
\hline 4 & $\begin{array}{l}\text { Number of healthy teeth suafaces } \\
\text { Number of DF surfaces } \\
\text { Rate of DF surfaces (\%) } \\
\text { Caries inhibition rate (\%) }\end{array}$ & $\begin{array}{r}2,944 \\
199 \\
6.76 \\
\end{array}$ & $\begin{array}{r}3,389 \\
202 \\
5.96 \\
11.8\end{array}$ & $\begin{array}{r}3,814 \\
196 \\
5.14 \\
24.0\end{array}$ & $\begin{array}{r}3,672 \\
194 \\
5.28 \\
21.9\end{array}$ & $\begin{array}{c}5.79 \\
19.2\end{array}$ \\
\hline \multirow[t]{3}{*}{5} & $\begin{array}{l}\text { Number of healthy teeth surfaces } \\
\text { Number of DF surfaces } \\
\text { Rate of DF surfaces (\%) } \\
\text { Caries inhibition rate (\%) }\end{array}$ & $\begin{array}{r}3,802 \\
192 \\
5.05 \\
\end{array}$ & $\begin{array}{r}4,069 \\
196 \\
4.82 \\
4.6\end{array}$ & $\begin{array}{r}3,942 \\
152 \\
3.86 \\
23.6\end{array}$ & $\begin{array}{r}5,206 \\
231 \\
4.44 \\
12.1\end{array}$ & $\begin{array}{c}4.54 \\
13.9\end{array}$ \\
\hline & Mean DF surface rate (\%) & 6.92 & 6.22 & 5.41 & 5.73 & \\
\hline & Mean caries inhibition rate $(\%)$ & - & 9.4 & 22.3 & 16.8 & \\
\hline
\end{tabular}

in Fig 5. It is $6.92 \%$ in the $\mathrm{C}$ dentifrice group, $6.22 \%$ in the $\mathrm{M}$ dentifrice group, $5.73 \%$ in the MP dentifrice group, and $5.41 \%$ in the MD dentifrice group. It is $7.89 \%$ in the third grade, $5.79 \%$ in the fourth group, and $4.54 \%$ in the fifth grade, thus showing a decreasing tendency with age.

Significances between dentifrice groups are shown in Table 14. There is a significance with $1 \%$ risk for each between the $C$ dentifrice group and the $M, M D, M P$ dentifrice groups. There is also a significance with $1 \%$ risk between the $\mathrm{M}$ and MP dentifrice groups.

The mean caries inhibition rate on molars in grades is $9.4 \%$ in the $\mathrm{M}$ group, $22.3 \%$ in

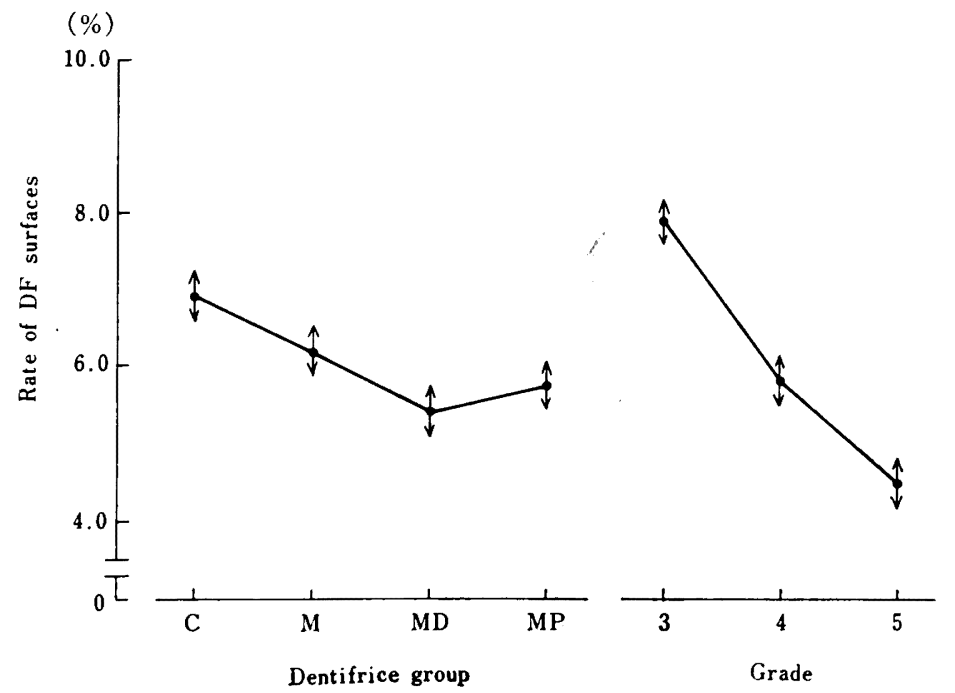

Fig. 5 A graph of interval estimation of molar surfaces. 
Table 14. Comparison of significance between dentifrice groups on molar surface

\begin{tabular}{|c|c|c|c|}
\hline Dentifrice group & M & $\mathrm{MD}$ & MP \\
\hline \multirow[t]{3}{*}{$\mathrm{C}$} & $* *$ & $* *$ & $* *$ \\
\hline & M & $($ effect of $+D)$ & $($ effect of $+\mathrm{P})$ \\
\hline & & $\mathrm{MD}$ & $\begin{array}{l}\text { (difference between effect of } \\
+D \text { and that of }+P \text { ) }\end{array}$ \\
\hline
\end{tabular}

the MD dentifrice group, and $16.8 \%$ in the MP dentifrice group. An addition of dextranase increased caries inhibition rate by $12.9 \%$ and that of sodium phosphate by $7.4 \%$. The mean caries inhibition rate in the third grade is $15.9 \%$, and $19.2 \%$ in the fourth, $13.9 \%$ in the fifth grade.

4) Classifying molars into mesial-distal surfaces, buccal-lingual surfaces, and occlusal surfaces.

The data for existing molars are classified by surfaces, as shown in Table 15, 16, 17.

As to mesial-distal surfaces of molars, the rate of DF surcfaces in $C, M, M D$, and $M P$ dentifrice groups is $1.87 \%, 1.77 \%, 1.81 \%$ and $1.80 \%$ respectively shown in Table 15 , close to each other. Therefore no significance was demonstrated in variance analysis.

Significance with $1 \%$ risk was found in grades. The mean DF surface rate in each grade is $2.30 \%$ in the third, $1.57 \%$ in the fourth, and $1.64 \%$ in the fifth grade, the

Table 15. Rate of DF surfaces and caries inhibition rate on mesial-distal surfaces of molars

\begin{tabular}{|c|c|c|c|c|c|c|}
\hline \multirow{2}{*}{ Grade } & \multirow{2}{*}{ Item } & \multicolumn{4}{|c|}{ Dentifrice group } & \multirow{2}{*}{ Mean (\%) } \\
\hline & & $\mathrm{C}$ & M & $\mathrm{MD}$ & MP & \\
\hline \multirow{4}{*}{3} & Number of healthy teeth surfaces & 904 & 1,163 & 1,258 & 875 & \multirow{4}{*}{$\begin{array}{l}2.30 \\
7.0\end{array}$} \\
\hline & Number of DF surfaces & 22 & 26 & 27 & 21 & \\
\hline & Rate of DF surfaces (\%) & 2.43 & 2.23 & 2.15 & 2.40 & \\
\hline & Caries inhibition rate $(\%)$ & $\longrightarrow$ & 8.2 & 11.5 & 1.2 & \\
\hline \multirow{4}{*}{4} & Number of healthy teeth surfaces & 1,310 & 1,513 & 1,700 & 1,633 & \multirow{4}{*}{$\begin{array}{c}1.57 \\
14.6\end{array}$} \\
\hline & Number of DF surfaces & 23 & 21 & 28 & 24 & \\
\hline & Rate of DF surfaces (\%) & 1.76 & 1.39 & 1.65 & 1.47 & \\
\hline & Caries inhibition rate $(\%)$ & $\longrightarrow$ & 21.0 & 6.3 & 16.5 & \\
\hline \multirow{4}{*}{5} & Number of healthy teeth surfaces & 1,677 & 1,775 & 1,729 & 2,285 & \multirow{4}{*}{$\begin{array}{l}1.64 \\
6.8\end{array}$} \\
\hline & Number of DF surfaces & 29 & 30 & 28 & 35 & \\
\hline & Rate of DF surfaces $(\%)$ & 1.73 & 1.69 & 1.62 & 1.53 & \\
\hline & Caries inhibition rate $(\%)$ & $\overline{-}$ & 2.3 & 6.4 & 11.6 & \\
\hline \multicolumn{2}{|r|}{ Mean DF surface rate $(\%)$} & 1.87 & 1.77 & 1.81 & 1.80 & \\
\hline & Mean caries inhibition rate $(\%)$ & 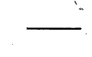 & 10.5 & 8.1 & 9.8 & \\
\hline
\end{tabular}


Table 16. Rate of DF surfaces and caries inhibition rate on buccal-lingual surfaces of molars

\begin{tabular}{|c|c|c|c|c|c|c|}
\hline \multirow{2}{*}{ Grade } & \multirow{2}{*}{ Item } & \multicolumn{4}{|c|}{ Dentifrice group } & \multirow{2}{*}{ Mean (\%) } \\
\hline & & $\mathrm{C}$ & $\mathrm{M}$ & MD & MP & \\
\hline \multirow{4}{*}{3} & Number of healthy teeth surfaces & 867 & 1,098 & 1,180 & 828 & \\
\hline & Number of DF surfaces & 86 & 80 & 79 & 62 & \\
\hline & Rate of DF surfaces $(\%)$ & 9.92 & 7.29 & 6.69 & 7.49 & 7.85 \\
\hline & Caries inhibition rate $(\%)$ & & 26.5 & 32.6 & 24.5 & 27.9 \\
\hline \multirow{4}{*}{4} & Number of healthy teeth surfaces & 1,248 & 1,423 & 1,587 & 1,529 & \\
\hline & Number of DF surfaces & 96 & 94 & 82 & 88 & \\
\hline & Rate of DF surfaces (\%) & 7.69 & 6.61 & 5.17 & 5.76 & 6.31 \\
\hline & Caries inhibition rate (\%) & - & 14.0 & 32.8 & 25.1 & 24.0 \\
\hline \multirow{4}{*}{5} & Number of healthy teeth surfaces & 1,580 & 1,707 & 1,650 & 2,177 & \multirow{4}{*}{$\begin{array}{c}4.69 \\
18.9\end{array}$} \\
\hline & Number of DF surfaces & 86 & 86 & 63 & 97 & \\
\hline & Rate of DF surfaces (\%) & 5.44 & 5.04 & 3.82 & 4.46 & \\
\hline & Caries inhibition rate $(\%)$ & & 7.4 & 29.8 & 18.0 & \\
\hline & Mean DF surface rate (\%) & 7.68 & 6.31 & 5.23 & 5.90 & \\
\hline \multicolumn{2}{|c|}{ Mean caries inhibition rate $(\%)$} & - & 16.0 & 31.7 & 22.5 & \\
\hline
\end{tabular}

Table 17. Rate of DF surfaces and caries inhibition rate on occlusal surfaces of molars

\begin{tabular}{|c|c|c|c|c|c|c|}
\hline \multirow{2}{*}{ Grade } & \multirow{2}{*}{ Item } & \multicolumn{4}{|c|}{ Dentifrice group } & \multirow{2}{*}{ Mean (\%) } \\
\hline & & $\mathrm{C}$ & M & MD & MP & \\
\hline \multirow{4}{*}{3} & Number of healthy teeth surfaces & 250 & 298 & 344 & 248 & \\
\hline & Number of DF surfaces & 73 & 96 & 95 & 63 & \\
\hline & Rate of DF surfaces $(\%)$ & 29.20 & $\begin{array}{c}32.21 \\
(28.53)\end{array}$ & 27.62 & 25.40 & \\
\hline & Caries inhibition rate $(\%)$ & - & $\begin{array}{r}-10.3 \\
(2.3)\end{array}$ & 5.4 & 13.0 & $\begin{array}{l}2.7 \\
(6.9)\end{array}$ \\
\hline \multirow{4}{*}{4} & Number of healthy teeth surfaces & 386 & 453 & 527 & 510 & \\
\hline & Number of DF surfaces & 80 & 87 & 86 & 82 & \\
\hline & Rate of DF surfaces (\%) & 20.73 & 19.21 & 16.32 & 16.08 & 18.07 \\
\hline & Caries inhibition rate $(\%)$ & - & 7.3 & 21.3 & 22.4 & 17.0 \\
\hline \multirow{4}{*}{5} & Number of healthy teeth surfaces & 545 & 592 & 563 & 744 & . \\
\hline & Number of DF surfaces & 77 & 80 & 61 & 99 & \\
\hline & Rate of inhibition rate $(\%)$ & 14.13 & 13.51 & 10.83 & 13.31 & 12.95 \\
\hline & Caries inhibition rate $(\%)$ & - & 4.4 & 23.4 & 5.8 & 11.2 \\
\hline & Mean DF surface rate $(\%)$ & 21.35 & $\begin{array}{c}21.64 \\
(20.42)\end{array}$ & 18.26 & 18.26 & \\
\hline & Mean caries inhibition rate $(\%)$ & - & $\begin{array}{c}0.5 \\
(4.7)\end{array}$ & 16.7 & 13.7 & \\
\hline
\end{tabular}

Figures in parenthesis are sought by using a substituting value. 


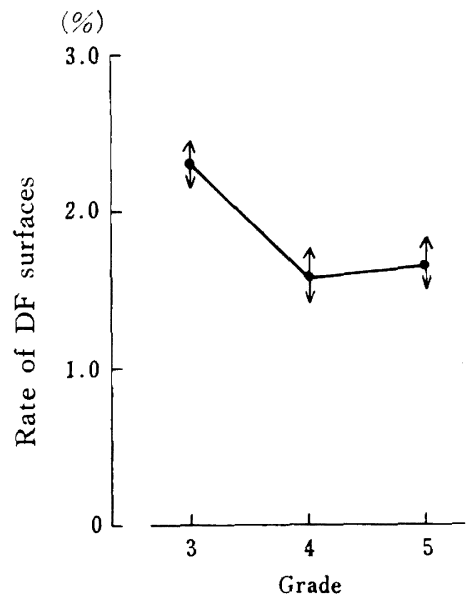

Fig. 6 A graph of interval estimation of mesial-distal surfaces of molars.

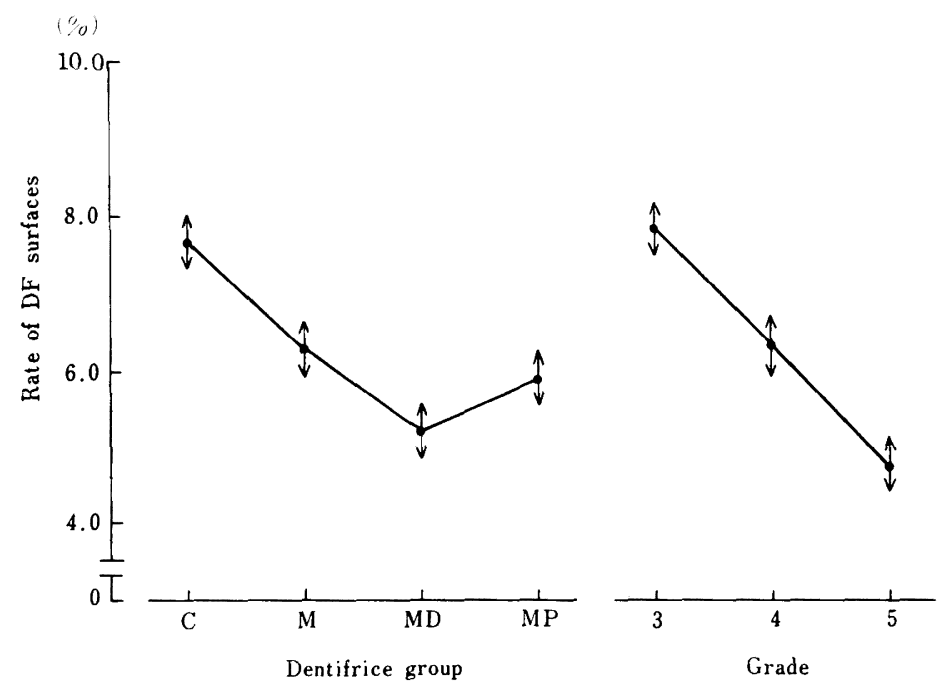

Fig. 7 A graph of interval estimation of occlusal surfaces of molars.

Table 18. Comparison of significance on buccal-lingual surface between dentifrice groups

\begin{tabular}{|c|c|c|c|}
\hline Dentifrice group & $\mathbf{M}$ & $\mathrm{MD}$ & MP \\
\hline C & $* *$ & $* *$ & $* *$ \\
\hline & $M$ & $\left(\right.$ effect ${ }^{*}$ of $\left.+\mathrm{D}\right)$ & $($ effect of $+\mathrm{P})$ \\
\hline & & $\mathrm{MD}$ & $\begin{array}{l}\text { (difference between effect } \\
\text { of }+\mathrm{D} \text { and that of }+\mathrm{P} \text { ) }\end{array}$ \\
\hline
\end{tabular}

** : Significant difference with $1 \%$ risk.

* : Significant difference with $5 \%$ risk. 
percentages of the latter two being reversed, hence fluctuation in the data is assumed. A graph of interval estimation is shown in Fig. 6.

As to buccal-lingual surfaces of molars, variance analysis resulted in significance with $1 \%$ risk both in dentifrice groups and grade. The rate of DF surfaces is $7.68 \%$ in the $\mathrm{C}$ dentifrice group, $6.31 \%$ in the M, 5.90\% in the MP and $5.23 \%$ in the MD dentifrice group.

It is $7.85 \%$ in the third, $6.31 \%$ in the fourth, and $4.69 \%$ in the fifth grade, showing a decreasing tendency with increase of age.

Significances between the dentifrice groups are shown in Table 18. There is a significance with $5 \%$ risk between the $\mathrm{C}$ and $\mathrm{M}$ dentifrice groups, with $1 \%$ risk for each between the $\mathrm{C}$ and MP dentifrice groups, the $\mathrm{C}$ and MD dentifrice groups, and with $5 \%$ risk between the $\mathrm{M}$ and $\mathrm{MD}$ dentifrice groups.

The mean caries inhibition rate in grades is $16.0 \%$ in the $\mathrm{M}, 31.7 \%$ in the $\mathrm{MD}$, and $22.5 \%$ in the MP dentifrice groups. An addition of dextranase increased caries inhibition rate by $15.7 \%$ and that of sodium phosphate by $6.5 \%$. The mean caries inhibition rate is $27.9 \%$ in the third, $24.0 \%$ in the fourth, and $18.9 \%$ in the fifth grade.

As to the occlusal surfaces of molars the mean DF surface rate in the $\mathrm{M}$ dentifrice group is $21.64 \%$, that in the $\mathrm{C}$ is $21.35 \%$, that in the MD is $18.26 \%$ and that in the MP dentifrice group is $18.26 \%$. Here the rate in the $M$ dentifrice group is higher than that in the $C$, which resulted from the data of the third grade in the $M$ dentifrice group, where the rate of $\mathrm{DF}$ surfaces in the $\mathrm{C}, \mathrm{M}, \mathrm{MD}$ and $\mathrm{MP}$ dentifrice groups at the beginning of the study was $45.77 \%, 49.15 \%, 46.00 \%$ and $44.14 \%$ respectively, much higher than those in other groups, showing that the subjects in the $\mathrm{M}$ dentifrice group had higher caries incidence.

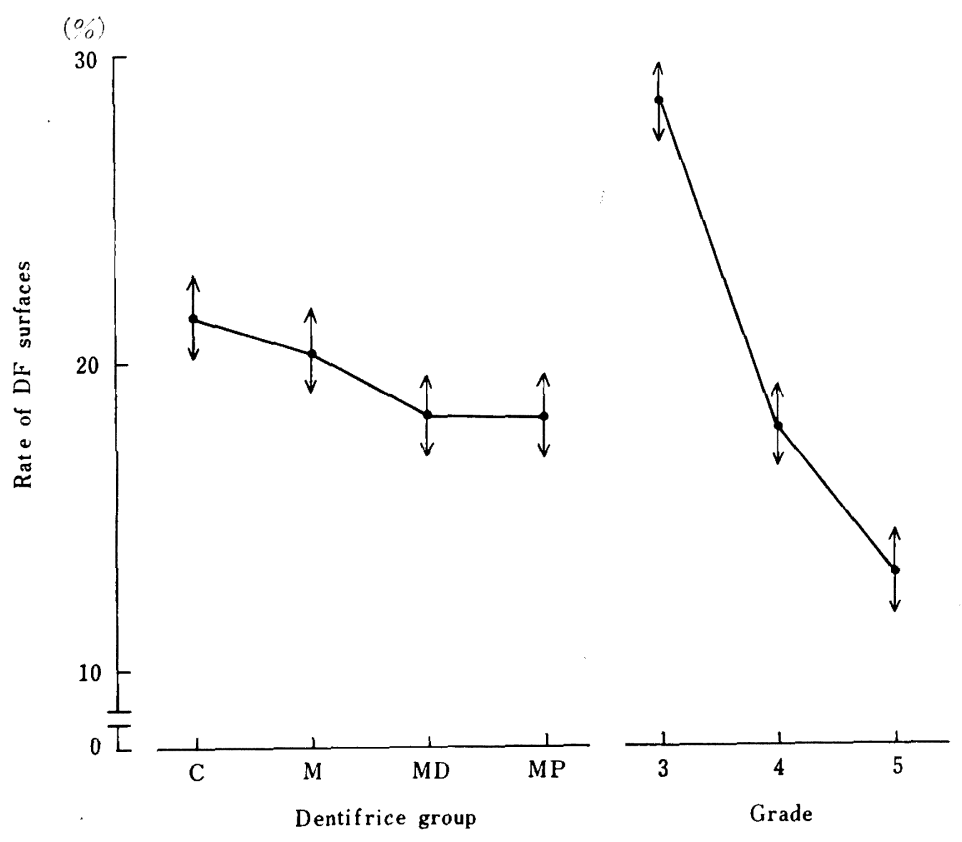

Fig. 8 A graph of interval estimation of occlusal surfaces of molars. 
Table 19. Comparison of significance on occlusal surfaces between dentifrice groups

\begin{tabular}{|c|c|c|c|}
\hline Dentifrice group & $\mathrm{M}$ & $\mathrm{MD}$ & MP \\
\hline \multirow[t]{3}{*}{$\mathrm{C}$} & - & $*$ & * \\
\hline & $\mathrm{M}$ & $($ effect of $+D)$ & $($ effect of $+P)$ \\
\hline & & $\mathrm{MD}$ & $\begin{array}{l}\text { (difference between effect } \\
\text { of }+D \text { and that of }+P \text { ) }\end{array}$ \\
\hline
\end{tabular}

*: Significant difference with $5 \%$ risk.

The rate of DF surface of the $M$ dentifrice group of the third grade, $32.21 \%$, is regarded as an abnormal value, and the method ${ }^{34)}$ used for computing the substitutioning value of the defective one with two-way lay out with data in Table 17, the rate of DF surfaces in the $M$ dentifrice group is calculated at $28.53 \%$ as shown in parenthesis in Table 17 . Variance analysis with the substitutioning value results in significance with $7 \%$ risk in dentifrice groups, and with $1 \%$ risk in grade.

The rate of DF surfaces in each dentifrice group is shown in Table 17 and in Fig. 8: $21.35 \%$ in the $\mathrm{C}, 20.42 \%$ in the $\mathrm{M}, 18.26 \%$ in both the MD and MP dentifrice groups.

It decreases with increases of age showing $28.61 \%$ in the third, $18.07 \%$ in the fourth, and $12.95 \%$ in the fifth grade. Significance between dentifrice groups is shown in Table 19. There is significance with $5 \%$ risk between the $\mathrm{C}$ and $\mathrm{MD}$, the $\mathrm{C}$ and MP dentifrice groups for each.

As to caries inhibition rate on occlusal surfaces, the mean value in grades is $4.7 \%$ in the $\mathrm{M}, 16.7 \%$ in the $\mathrm{MD}$, and $13.7 \%$ in the MP dentifrice group. An addition of dextranase increases the caries inhibition rate $12.0 \%$, and that of sodium phosphate increases $9.0 \%$. The highest mean caries inhibition rate is $17.0 \%$ in the fourth grade, followed by $11.2 \%$ in the fifth, and $6.9 \%$ in the third grade.

Therefore the highest caries inhibition effect of monoflo is observed on buccal-lingual surfaces of molars, followed by on mesial-distal surfaces, and occlusal surfaces.

The greatest caries inhibition effect caused by an addition of dextranase is observed also on buccal-lingual surfaces, followed by occlusal surfaces, but none in mesial-distal surfaces. In the case of an addition of sodium phosphate, the greatest caries inhibition effect is observed on occlusal surfaces, followed by buccal-lingual surfaces, but none in mesial-distal surfaces.

No subjects in four dentifrice groups complained of intraoral anomalies over the period of one year. No anomalies which might be caused by these four dentifrices were found at oral examinations, either.

\section{Examination}

Three kinds of fluoride, mainly stannous fluoride $\left(\mathrm{SnF}_{2}\right)$, sodium fluoride $(\mathrm{NaF})$ and 
monoflo, are used in dentifrice, of which monoflo has different characteristics from the others. Generally stannous fluoride and sodium fluoride take a form of free $\mathrm{F}^{-}$ion in an aqueous solution, while monoflo takes a form of complex ion $\mathrm{PO}_{3} \mathrm{~F}^{2-}$, which produces little insoluble salt at an additive concentration to dentifrice contrast to an action of free $\mathrm{F}^{-}$ion. For instance, free $\mathrm{F}^{-}$ion changes to $\mathrm{CaF}_{2}$, and $\mathrm{PO}_{3} \mathrm{~F}^{2-}$ to $\mathrm{CaPO}_{3} \mathrm{~F}$, when both ions combine with calcium ion. The latter has about $1 \%$ of solubility at $20^{\circ} \mathrm{C}$, which is several hundred times greater than that of the former ${ }^{15}$.

This chemical characteristics of monoflo is great use in application to dentifrice containing much calcium salt such as calcium phosphate or calcium carbonate. Monoflo is said to be of lower toxicity for taking the form of a complex salt than sodium fluoride ${ }^{15,35,36}$. The study done by Ericsson ${ }^{37)}$ has described a different function of monoflo in caries prevention compared to those of former fluoride.

It is assumed that the action of $\mathrm{SnF}_{2}$ and $\mathrm{NaF}$ will get greater with a higher acid, accompanying a destruction of tooth substance. However an aqueous solution of monoflo is neutral, and so produces fluorapatite without destroying tooth substance. Furthermore dentifrice containing monoflo is reported to be effective in hypersensitiveness of teeth ${ }^{38)}$.

Of clinical experiments of monoflo added dentifrice, many studies by Finn and others $^{4)}$, Naylor and others ${ }^{6)}$, Fanning and others ${ }^{91}$, and M $\phi$ ller and others ${ }^{10)}$, Takeuchi and others $^{11)}$, Onishi and others ${ }^{12)}$ have been published, achieving encouraging caries prevention effects. Those achievements cannot be compared with each other simply, for subjects and methods are different. They show about $20 \%$ to $30 \%$ caries inhibition rate in DMFS as a whole.

Caries inhibition rate of monoflo added dentifrice is $25.5 \%$ of all teeth in the present study, which seems to be adequate compared to the previous data.

In 1967, Gibbons and others ${ }^{39)}$, Wood and others ${ }^{40)}$, Leach and others ${ }^{41)}$, Crithley and others $^{42)}$ and Guggenheim and others ${ }^{43}$ reported that many viscous extra-cellular polysaccharides were produced from sucrose by cariogenic streptococci and that the product is mainly dextran, which was a major polysaccharide of dental plaque matrix.

Caries attack is thought to begin below plaque and it is expected that plaque formation and caries attack can be prevented through an action of an enzyme of dextranase which analyses dextran, a major component of the sticky substance in plaque.

Fitzgerald and others ${ }^{21)}$ reported that they had inoculated hamsters with cariogenic streptococci and fed them on a diet and drinking water containing dextranase, which had resulted in a significant prevention of plaque deposition and caries attack. Block and others ${ }^{22}$ and König ${ }^{44,45)}$ also reported similar experiments. Bowen ${ }^{23)}$ reported that caries had been apparently inhibited after monkeys had been fed on a diet containing dextranase for 3 years.

Lobene $^{17)}$ reported that a rinsing with a gargle containing dextranase 8 times a day in adult men 18 to 24 years of age resulted in about $30 \%$ less plaque deposition contrasted to the control not using the enzyme. Coldwell and others ${ }^{46)}$ and Keyes and others ${ }^{47}$ ) conducted similar experiments with adult men and women, and reported that an experimental group had resulted in a smaller amount of plaque deposition than a control group, but without a statistically significant difference. $\mathrm{Baba}^{20)}$, one of authors of the present 
study, reported that a using of the dentifrice without abrasive agent and containing dextranase derived from Chaetomium gracile, the same as that used in the present study, twice daily morning and evening in adult men and women resulted in segnificantly less plaque deposition contrasted to the control. However reports about caries prevention effect of dextranase in men have not been published as yet.

When this dextranase is added to monoflo, first it produces caries prevention effect by its action on plaque, and next the effect is increased by monoflo producing ease of action on teeth surfaces.

In the present study, a high caries inhibition rate of $42.3 \%$ is obtained for data of all teeth, when Chaetomium gracile dextranase 15,000 units/g dentifrice is added to monoflo. Therefore the difference of $16.8 \%$ between the rate $42.3 \%$ and $25.5 \%$ achieved by monoflo alone is the rate of caries inhibition effect achieved by an addition of dextranase. In order to measure the mentioned two effects individually, it is necessary to use dentifrice which only dextranase is added and to evaluate the amount of dextranase to be added, which cannot be realized in this study, for the number of subjects is not sufficient.

Studies of the relation between phosphates and caries has begun with a report by Nizel and Harris ${ }^{48,49,50)}$ that the administration of two types of corn and milk, the products from different districts, to hamsters resulted in a difference of $4 \%$ in caries incidence, which the reporters found to be due to a cariostatic agent, that was phosphate, contained in corn and milk. The function of caries prevention of phosphates is considered to be buffering of plaque to acid in the oral cavity in a direct way or through the salivary gland, and recalcification of teeth ${ }^{24)}$. The effect has been reported to differ according to chemical constitution of phosphates or types of cation combined with phosphates ${ }^{51)}$. Of those phosphates, sodium phosphate has a greater caries inhibition effect than that of insoluble $\mathrm{CaHPO}_{4}$, but the effect is lost if directly injected into the intestine, so the effect is achieved through topical use in mouth ${ }^{52)}$. Wynn and others ${ }^{53)}$ obtained $42 \%$ to $70 \%$ of caries inhibition rate through an experiment where rats were fed on the diet in which $\mathrm{Na}_{2} \mathrm{HPO}_{4}$ and $\mathrm{NaH}_{2} \mathrm{PO}_{4}$ were mixed in the ratio of $1: 1$. Stookey and others ${ }^{25)}$ added these agents to the breakfast of schoolchildren 5 to 16 years of age, and obtained $20 \%$ to $40 \%$ of caries inhibition rate after two years of the study. But reports of the effects caused by these substances added to dentifrice have not been published yet. Another report that an administration of fluorides accompanied by sodium phosphate resulted in a greater effect has been published ${ }^{54)}$.

In the present study, a caries inhibition rate of $30.1 \%$ is obtained for data of all teeth, when $3 \%$ sodium phosphate is added to monoflo. Therefore the difference of $4.6 \%$ between the rate $30.1 \%$ and $25.5 \%$ achieved by monoflo alone is the rate of caries inhibition effect achieved by an addition of sodium phosphate. But a statistically significant diference is not observed between the monoflo group and the monoflo and sodium phosphate group, which may be due to a similarity of monoflo and sodium phosphate in respect to additive concentration and strengthening of tooth substance through recalcification ${ }^{55)}$.

When data of all teeth is classified by tooth surface, the efficiency of three different dentifrice can be observed on existing teeth surfaces and molar surfaces with high caries incidence. 
On newly erupted teeth surfaces and anterior teeth surfaces an adaptation of a longer period of clinical experiments and greater number of subjects could make the effects known.

Onishi and others ${ }^{12)}$ reported the effectiveness of dentifrice containing monoflo on smooth surfaces and in pits and fissures. In the present study monoflo has been highly effective on buccal-lingual surfaces, but not on mesial-distal surfaces and occlusal surfaces and so with the effect of an addition of dextranase and sodium phosphate, except for a little effectiveness on occlusal surfaces. Both dextranase and sodium phosphate are aqueous, and the former is effective in caries prevention in animal experiments using hamster $\mathrm{s}^{21,22)}$, and the latter on adjacent surfaces. Therefore caries prevention effects by an addition of both agents were expected to have been observed also on mesial-distal surfaces. The reverse result against expectation might be due to less caries incidence and dispersion in data which was caused by not grouping subjects by tooth surface at the beginning of the study. It is also guessed from data in Table 15 that the order of caries inhibition rate in dentifrice group is not same in the three grades.

The observation of an abnormal value in the $M$ dentifrice group on occlusal surfaces in data of the third grade may be due to a greatly higher rate of DF surfaces than those of the other dentifrice groups at the beginning of the study. Therefore classification and grouping at the beginning of the study may be important, particularly in the case of low caries incidence.

\section{Conclusion}

Schoolchildren in the third, fourth, and fifth grade in elementary schools used three different dentifrices for one year, monoflo containing, monoflo and dextranase containing, and monoflo and sodium phosphate containing dentifrices respectively. The caries prevention effects have been evaluated and the following results obtained.

1) The group using a dentifrice to which $0.76 \%$ monoflo was added have shown a statistically lower rate of DF surfaces increasing during the study period compared to that of the control group, and $25.5 \%$ caries inhibition rate has been observed in the former.

2) There has been a significant difference between the group using a dentifrice where 15,000 units/g dentifrice of dextranase was added to monoflo and the group using a dentifrice monoflo alone, and an addition of dextranase has increased the caries inhibition rate by $16.8 \%$.

3 ) In the group using a dentifrice which $3 \%$ sodium phosphate was added to monoflo, $4.6 \%$ higher caries inhibition rate has been observed compared to the case of the group using a dentifrice with monoflo alone, but a significant difference in increased DF surface rate between them has not been found.

4) An evaluation of caries inhibition rate of 3 dentifrices by type of teeth has resulted in a similar finding as the above, but with a little lower inhibition rate on existing teeth surfaces and molar surfaces. An effect produced by an addition of sodium phosphate on molar surfaces has been statistically significant.

5) An evaluation of molars by surface has resulted in the finding of an effectiveness of monoflo on smooth surfaces and occlusal surfaces of molars. An addition of dextranase and 
that of sodium phosphate has been effective on buccal-lingual surfaces and occlusal surfaces of molars, but those effects have not been observed on mesial-distal surfaces.

6) No adverse effects of these four dentifrices were observed in subjective or objective conditions through a continuous use over the period of one year.

\section{Acknowledgement}

The authors are greatly indebted to the Board of Education and the School Dental Association of Kanagawa Prefecture, and elementary schools for investigation, and to the Lion Dentifrice Co., Ltd. for an offer of studying materials.

The essential points of this study were published at the Meeting of the Japanese Association for Dental Health, and the 17th Kanto District Meeting on Feb. 24, 1973, and at the 22nd General Meeting of the Japanese Association for Dental Health on Sept. 26, 1973.

\section{References}

1) Muhler, J. C., Radike, A. W., ivebergall, W. H. and Day, H. G.: The effect of a stannous fluoride containing dentifrice on caries reduction in children; J. dent. Res., $33: 606,1954$.

2) Jordan, W. A. and Peterson, J. K. : Cariesinhibiting value of a dentifrice containing stannous fluoride : final report of a two year study; J. Amer. dent. Ass., 58 : 42, 1959.

3) Yokoyama, G. and Watanabe, S.: A study on caries prevention effects of fluoride (sodium fluoride) containing dentifrice; J. J. S. S., $10: 339,1961$.

4) Finn, S. B. and Jamison, H. C. : A comparative clinical study of three dentifrices; J. dent. Child, $30: 17,1973$.

5) Brudevold, F. and Chilton, N. W.: Comparative study of a fluoride dentifrice containing soluble phosphate and a calcium-free abrasive: second year report; J. Amer. dent. Ass., 72 : 889, 1966.

6) Naylor, M. N. and Emislie, R. D. : Clinical testing of stannous fluoride and sodium monofluorophosphate dentifrices in London schoolchildren; Brit. dent. J., 123:17, 1967.

7) James, P. M. C. and Anderson, R. J. : Clinical testing of stannous fluoride-calcium pyrophosphate dentifrice in Buckinghamshire school children; Brit. dent. J., 123 : 33, 1967.

8) Onishi, E., Okada S., Hinoide, M., Akada, K., Kon, K., Sugano, N., Sakakibara Y., Morita, J. and Imamura, Y.: Effect of stannous fluoride dentifrice of dental caries on the reduction in schoolchildren; J. dent. Hlth, $17: 5,1967$.

9) Fanning, E. A., Gotjamanos, T. and Vowles, N. J.: The use of fluoride dentifrices in the control of dental caries: Methodology and results of a clinical trial; Aust. dent. J., $13: 201,1968$.

10) M $\phi$ ller, I. J. Holst, J. J. and S $\phi$ rensen, E. : Caries reducing effect of a sodium monofluorophosphate dentifrice; Brit. dent. J., $124: 209,1968$.

11) Takeuchi, M., Shimizu, A., Kawasaki, T. and Kizu, T.: A field study on effect of a dentifrice containing sodium monofluorophosphate in caries prevention; J. Dent. Hith, $18: 26,1968$.

12) Onishi, M. and Tani, H.: Clinical trial on the reduction of caries incidence by use of two different fluoride dentifrices; J. Dent. Hlth, $20:$ 105, 1970.

13) Drug approval and licensing procedures in Japan edited by Society of Japanese Pharmcopoeia; Yakuji-Jiho Co. Ltd, Tokyo, 353 pp., 1972.

14) Muhler, J. C.: The effect of a modified stannous fluoride calcium pyrophosphate dentifrice on dental caries in children; J. dent. Res., 37 : 448, 1958.

15) Shourie, K. L., Hein, J. W. and Hodge, H. C.: Preliminary studies of the caries inhibiting potential and acute toxicity of sodium monofluorophosphate; J. dent. Res., 29 : 529, 1950.

16) Murayama, Y., Tsuchimoto, M., Hayashi, H., Uchida, T., and Yokomizo, I.: Ex- 
perimental studies of the effect of dextranase on human dental plaque; J. Jap. Ass. Periodont., 13 : 68, 1971.

17) Lobene, R. R.: A clinical study of the effect of dextranase on human dental plaque; J. Amer. dent. Ass., 82 : 132, 1971.

18) Murayama, Y., Mihara, T. and Hayashi, H.: The clinical effect of dextranase for Spicaria violaceae on human dental plaque ; J. Jap. Ass. Periodont., 16 : 69, 1974.

19) Baba, K.: A study of characters of dextranase derived from Chaetomium gracile, and of its influence on polysaccharide produced by Str. mutans and on human dental plaque; Under contribution.

20) Baba, K.: Control effects on human plaque formation of dentifrice containing dextranase derived from Chaetomium gracile; Under contribution.

21) Fitzgerald, R. J., Keyes, P. H., Stoudt, T. H. and Spinell, D. M. : The effects of a dextranase preparation on plaque and caries in hamsters. A preliminary report; J. Amer. dent. Ass., 76 : 301, 1968.

22) Block, P. L., Doley, G. L. and Howe, E. E. : The retardation of spontaneous periodontal disease and the prevention of caries in hamsters with dextranase; J. Periodont, 40 : 105, 1969.

23) Bowen, W. H. : The effect of dextranase on carious activity in monkeys (Macaca irus); Brit. dent. J., 131 : 445, 1971.

24) Brudevold, F., Amdur, B. H., Vogel, J. J. and Spinell, M.: Effect of ingested supplementary phosphate on the tooth surface; J. dent. Res, 43 : 1168, 1564.

25) Stookey, G. K., Carroll, R. A. and Muhler, J. C.: The clinical effectiveness of phosphate-enriched breakfast cereals on the incidence of dental caries in children: results after 2 years; J. Amer. dent. Ass., $74: 752,1967$.

26) Inoue, T. and Masuda, H. : Acute toxicity reaction of dextranase in mice and rats; Unpublished.

27) Suzuki, Y., Masuda, H., Kanamaru, M., Irie, Y., Matsunuma, S., Kaiho, S., Shimazaki, A. and Kogure, K.: Toxicity of dextranase in rats: an oral administration for five, and 26 continuous weeks; Unpublished.

28) Fukami, S. and Niuchi, T.: An evaluation of influence of dextranase on skin and mucosa ; Unpublished.

29) Suzuki, Y, Akuzawa, M., Takagi, K.,
Muramatsu, T., Yamashita, K., Maita, K., Okada, T. and Masuda, H.: Toxicity examination of dextranase in rabbits through skin for five weeks; Unpublished.

30) Suzuki, Y., Sudo, S., Akuzawa, M., Ifhiyama, K., Yamashita, K. and Masuda, H. : A study on influence of dextranase on leukocyte; Unpublished.

31) Takimoto, K. : A study of effectiveness of dentifrice containing dextranase and its influence on oral mucosa; J. Dent. Hlth, 25 : 1-29, 1975.

32) Greenlhalgh, R. and Riley, J. P.: The determination of fluorides in natural water with particular reference to sea water; Anal. Chem. Acta., 25 : 179, 1961.

33) Taguchi, G.: Statistic Analysis ; Maruzen, Tokyo, 197 pp., 1966.

34) Heirs, J. W., Smith, F. A., Gardner, D. W., Downs, W. L., Mayneard, E. A. and Hodge, H. C. : Further studies of the caries inhibitory potential and acute toxicity of complex fluorides; J. dent. Res., $30: 466$, 1951.

35) Taguchi, G.: Statistic Analysis; Maruzen, Tokyo, 100 pp., 1966.

36) Linkins, R. C. and Zipkin, I. : In vivo absorption of fluorides from the gastra intestinal tract; J. dent. Res., 34:895, 1955.

37) Ericsson, Y.: The mechanism of the monofluorophosphate action on hydroxyapatite and dental enamel; Acta odont. Scand., $21: 341,1963$.

38) Kanouse, M. C. and Ash, Jr. M. M. : The effectiveness of a sodium monofluorophosphate dentifrice on dental hypersensitivity ; J. Periodont., 40 : 38-40, 1969.

39) Gibbons, R. J. and Banghart, S. B. : Synthesis of extracellular dextran by cariogenic bacteria and its presence in human dental plaque; Archs oral Biol., 12 : 11, 1967.

40) Wood, J. M. and Critchley, P. : The soluble carbohydrates of the plaque matrix; J. dent. Res., 46 : 129, 1967.

41) Leach, S. A., Critchley, P., Kolends, A. B. and Saxton, C. A. : Salivary glycoproteins as components of enamel integuments; Caries Res., 1 : 104, 1967.

42) Critchley, P., Wood, J. M., Saxton, C. A. and Leach, S. A.: The polymerisation of dietary sugars by dental plaque; Caries Res., 1 : 112, 1967.

43) Guggenheim, B. and Schroeder, H. E. : Biochemical and morphological aspects of 
extra-cellular polysaccharides produced by cariogenic streptococci ; Helv. Odont. Acta., 11 : 131, 1967.

44) König, K. G. and Guggenheim, B. : In-vivo effects of dextranase on plaque and caries; Helv. Odont. Acta., 12 : 48, 1968.

45) König, K. G. and Guggenheim, B. : Implantation of antibiotic-resistant bacteria and the production of dental caries in rats; Adv. Oral Biol., 3 : 217, 1968.

46) Caldwell, R. C., Sandham, H. J., Mann, Jr., W. V., Finn, S. B. and Formicala, A. J.: The effect of a dextranase on dental plaque in young adults and children; $\mathrm{J}$. Amer. dent. Ass., 82 : 124, 1971.

47) Keyes, P. H., Hicks, M. A., Goldman, B. M., Macabe, R. M. and Fitzgerald, R. J.; Dispersion of dextranase bacterial plaques on human teeth with dextranase; J. Amer. dent. Ass., 82 : 136, 1971.

48) Nizel, A. E. and Harris, R. S. : Effect of foods grown in different areas on the prevalence of dental caries in hamsters; Arch. Biochem., 26 : 155, 1950.

49) Harris, R. S., Nizel, A. E. and Gardner, D. S.: Effects of food ash and trace minerals upon dental caries in hamster;
Proc. 4th int, Congr. Nutr., pp. 195, 1957.

50) Harris, R. S. and Nizel, A. E. : Effects of food ash, phosphate, and trace minerals upon hasmter caries; J. dent. Res., 38 : 1142, 1964.

51) Nizel, A. E. and Harris, R. S. : The effects of phosphates on experimental dental caries: a literature review; J. dent. Res., $43: 1123,1964$.

52) McLIure, F. J. and Muller, A.: Further observations on the cariostatic effect of phosphates; J. dent. Res., 38 : 776, 1959.

53) Wynn, W., Haldi, J., Bentley, K. D. and Law, M. L.: Dental caries in the albino rat in relation to the chemical composition of the teeth and of the diet, II. Variation in the $\mathrm{Ca} / \mathrm{P}$ ratio of the diet induced by changing the phosphorus content; J. Nutr., 58 : 325, 1956.

54) Van Rean, R., Ostrom, C. A. and Berzinskas, U. J.: The cariostatic effect of dietary phosphate in the rat in the presence or absence of fluoride in the drinking water; Arch. Oral Biol., 7 : 587, 1962.

55) Baba, K. and Nagashima, A. : A study on remineralization of teeth by $\mathrm{Na}_{2} \mathrm{PO}_{3} \mathrm{~F}$; An appendix of J. Dent. Hlth, 21 : 105, 1971.

概要 : $\mathrm{Na}_{2} \mathrm{PO}_{3} \mathrm{~F}, \mathrm{Na}_{2} \mathrm{PO}_{3} \mathrm{~F}$ と Dextranase および $\mathrm{Na}_{2} \mathrm{PO}_{3} \mathrm{~F}$ と Sodium Phosphate 添加蒾磨刻の 能触予防効果に関する研究, 丹羽輝男*, 馬場久衛谈, 丹羽源男*. ソジウムモノフルオロフォスフェー ト（以下モノフロと略す）添加歯磨剤，モノフロとデキストラナーゼ添加歯磨剤およびモノフロとリン 酸ナトリウム添加歯磨剤を小学校の学童に 1 力年間使用させその苟蝕予防効果について検討した。モ， フロを $0.76 \%$ 添加した歯磨剤使用群は対照歯磨剂使用群に対して研究期間中に増加した DF 歯面率に おいて両者に統計的に有意な差が認められ，25.5\%の䟥蝕抑制率を示した。モノフロにデキストラナー ゼを歯磨剤 $1 \mathrm{~g}$ 当り 15,000 単位添加した 歯磨剂使用群とモノフロ単独添加歯磨剤使用群との間にも有 意な差がみられ，デキストラナーゼの添加によって抑制率は $16.8 \%$ 増加した。またモノフロにリン酸 ナトリウムを $3 \%$ 添加した歯磨剤使用群はモノフロ単独添加歯磨剤使用群に比べて抑制率が $4.6 \%$ 増加 したが，增加 DF 歯面率では統計的に有意な差はなかった。さらに歯種別ならびに歯牙部位別に，3 種 の歯磿剂の满蝕予防効果をも検討した。また，これら歯磨剤 4 種類の 1 年間にわたる連続使用におい て, 口腔内の自覚, 他覚的症状供異常は認められなかった。 